Giuseppe Milan*

ORCID: 0000-0002-1081-1750

Padwa, Włochy

\title{
Budowanie procesów międzykulturowych w trudnych czasach. Propozycja według myśli i dzieła Chiary Lubich
}

\section{Building Interculturality in Difficult Times. Chiara Lubich's "Thought-Life" Proposal}

\begin{abstract}
Summary: The thought and action of Chiara Lubich are very important for intercultural education. She has given us many theoretical and practical tools - reinforced by the testimony lived with the greatest coherence - to learn to be intercultural as people, but also as groups, as specific collective and cultural identities. Her experience can be told as an experience of education in dialogue, a micro-macro dialogue that unfolds from the immediate challenge of interpersonal relationships to widen to the areas of political, intercultural, interreligious relations. This article analyses some aspects of today's multicultural reality, which challenges the world of education, and - assuming the demanding perspective of interculturality - examines some of Chiara's proposals, which are based on the idea of a person-dialogue, person-relationship and intercultural person. These proposals, methodologically essential in
\end{abstract}

* Prof. dr Giuseppe Milan, profesor zwyczajny pedagogiki międzykulturowej. Wykładowca w Università degli Studi di Padova oraz w Istituto Universitario Sophia w Loppiano (k. Florencji). Redaktor naczelny czasopisma pedagogicznego Studium Educationis. Adres: FISPPA, Via Beato Pellegrino 28, Padova; e-mail: giuseppe.milan@unipd.it. 
the transition from reality-challenge to the goals indicated by interculturality, are effectively communicated by Lubich in his fundamental book "The Art of Loving", in which she presents the secrets for interpersonal, social, intercultural relations, the inescapable attitudes that are configured as "concrete love". Some passages are here quoted that present the pedagogical principles of reference according to Chiara $\mathrm{Lu}$ bich, taken from the lecture entitled "Uomo-Mondo" (1972), from the lecture held in Paris on December 17, 1996, when she received the UNESCO prize for "Peace Education", from the lectio magistralis held in Washington on $10^{\text {th }}$ November 2000 (Honorary doctoral Degree in Education from The Catholic University of America).

Keywords: intercultural education; dialogue; multiculturality; community; pedagogy of unity.

Streszczenie: Myśl i dzieło Chiary Lubich mają istotne znaczenie dla edukacji międzykulturowej. Lubich ma znaczący wkład teoretyczny i praktyczny - wzmocniony bardzo spójnym świadectwem jej życia - w uczenie ludzi bycia ,międzykulturowymi” zarówno indywidualnie, jak i jako grupy o specyficznych tożsamościach zbiorowych i kulturowych. Całe jej doświadczenie można określić jako doświadczenie edukacji w dialogu, dialogu mikro-makro, który rozwija się, począwszy od wyzwania, jakie stawia każda relacja międzyosobowa, która z czasem rozszerza się na obszary relacji politycznych, międzykulturowych, międzyreligijnych. W tym artykule przeanalizowano kilka aspektów codziennej rzeczywistości międzykulturowej, która stawia wyzwania światu edukacji, i - przyjmując wymagającą perspektywę interkulturowości - przebadano niektóre propozycje Chiary Lubich: są one osadzone na idei osoby-dialogu, osoby-relacji, osoby-międzykulturowości. Te wypracowywane wskazania, metodologicznie zasadnicze w przechodzeniu od rzeczywistości-wyzwania do celów wyznaczanych przez międzykulturowość, są czytelnie określone przez Lubich w jej fundamentalnym tekście Sztuka mitowania, w którym przedstawia „sekret” relacji międzyosobowej, społecznej, międzykulturowej - postawę niezbędną, która wyraża się w „konkretnej miłości”. Przytoczone zostały niektóre fragmenty przedstawiające podstawowe zasady pedagogicznego odniesienia Chiary Lubich, zaczerpnięte z jej tekstu Człowiek-świat (1972), z przemówienia w Paryżu 17 grudnia 1996 r. z okazji przyznania jej Nagrody UNESCO za Wychowanie dla pokoju oraz z lectio magistralis, która odbyła się w Waszyngtonie 10 listopada $2000 \mathrm{r}$. z okazji przyznania jej tytułu doktora honoris causa w zakresie pedagogiki.

Slowa kluczowe: wychowanie międzykulturowe; dialog; wielokulturowość; wspólnota; pedagogia jedności. 
Nikt nie ma wątpliwości, że nasze społeczeństwa są dzisiaj wielokulturowe, że zauważalne jest - jako skutek migracji ludzi - współistnienie osób, grup, wspólnot o różnych źródłach kulturowych. Ta wielokulturowość nie jest (jak niekiedy się mówi) zjawiskiem przypadkowym, ale jest to pewna strukturalna, obiektywna, niekwestionowana rzeczywistość, która charakteryzuje współżycie między ludźmi pod każdą szerokością geograficzną. Z pewnością jest to rzeczywisty problem, który rzuca specyficzne wyzwanie światu edukacji. Jestem przekonany, że ma on szczególne zadanie - podjąć zagadnienie współczesnej rzeczywistości w aspekcie międzykulturowości, czyniąc ją samą konkretnym, twórczym dialogiem pomiędzy odrębnymi „wyspami wielokulturowego archipelagu". Jest to nie tylko jakaś idealna wizja, lecz dotykająca nas rzeczywistość. W tej perspektywie międzykulturowość jest sytuowana na płaszczyźnie „utopii”, rozumianej nie jako złudzenie, lecz jako wyspa, która jeszcze nie istnieje, ale może powinna pojawić się, i do której możemy i powinniśmy coraz bardziej się przybliżać. Jest to wciąż coś „,niedokończonego", jakby horyzont, ku któremu należy dążyć, nadal otwarty „teren budowy", coś, co jednak powstaje, tworzy się dzięki małym, skromnym, codziennym krokom, krokom na polu edukacji.

W tym dążeniu pierwszoplanową rolę odgrywają wielcy „świadkowie”, czyli osoby zdolne do ukierunkowywania i przybliżania nas do celu oraz udostępnienia nam użytecznego kompasu wskazującego kierunek, wnosząc oryginalny i twórczy wkład myśli i działania.

Postacią mającą wielkie znaczenie dla międzykulturowości jest z pewnością Chiara Lubich (1920-2008), prawdziwa mistrzyni w tej dziedzinie. Dała nam ona wiele narzędzi teoretycznych i praktycznych, umocnionych niezwykle spójnym świadectwem życia, które uczą, jak być i realizować się w interkulturowości nie tylko jako pojedyncze osoby, lecz także jako zespoły ludzkie o wspólnotowej i kulturowej tożsamości. Jej doświadczenie życia można uważać za doświadczenie wychowania do dialogu, dialogu w wymiarze mikro i makro, który wyraża się w bezpośrednim wyzwaniu do poszerzania relacji interpersonalnych na obszary polityki, stosunków międzykulturowych i międzyreligijnych.

Pamiętam jak w Waszyngtonie, 10 listopada 2000 r., Chiara Lubich $\mathrm{z}$ okazji nadania jej doktoratu honoris causa w zakresie pedagogiki - rozpoczęła swój wykład, stwierdzając: „nasz Ruch i nasza historia mogą być postrzegane jako wielkie, niezwykłe wydarzenie wychowawcze" ${ }^{1}$. Podobnie

${ }^{1}$ Chiara Lubich, „Charyzmat jedności i pedagogika”, w: Chiara Lubich, Charyzmat jedności, red. Michele Vandeleene (Kraków: Fundacja Mariapoli, Wydawnictwo M, 2007), 313. 
możemy powiedzieć, że „nasz Ruch i nasza historia - dzięki charyzmatowi Chiary Lubich - są wielkim, niezwykłym wydarzeniem międzykulturowym". W wielu doświadczeniach przeżytych z inicjatywy Ruchu Focolari można dostrzec prawdziwe i typowe ,wydarzenia międzykulturowe”. Wystarczyłoby wspomnieć - jako przykład - że wiele szkół na świecie inspirowanych jest ideałem Chiary Lubich ${ }^{2}$, liczne są też - realizowane w różnych kontekstach - doświadczenia dialogu międzyreligijnego i międzykulturowe$\mathrm{go}^{3}$. Ponadto jest oczywiste, że te propozycje i doświadczenia nie są zarezerwowane wyłącznie dla członków Ruchu: są one adresowane do każdego człowieka, do każdej rzeczywistości kulturowej, co przejawia się w ich rozpowszechnianiu w całym świecie.

Mając to na uwadze, proponuję bardziej szczegółowo przyjrzeć się temu zagadnieniu, próbując także ukazać fundamenty i implikacje egzystencjalno-empiryczne, które wynikają z wizji i pedagogicznego podejścia Chiary Lubich.

\section{Pierwszy poziom analizy. Aspekty i wyzwania wobec rzeczywistości oraz propozycje Chiary Lubich}

Przede wszystkim możemy zadać sobie pytanie: w jakim sensie mówimy o wielokulturowości jako o ,wyzwaniu wobec rzeczywistości”? Jakie są elementy tej rzeczywistości i jakie odpowiedzi możemy znaleźć w myśli i w dziełach Chiary Lubich? W jakim sensie te odpowiedzi otwierają się na perspektywę międzykulturowości?

Oto synteza niektórych punktów do rozważenia, w odniesieniu do których zbliżamy się, chociaż w skrócie, do pewnych cech myśli i dzieł wskazanych przez Lubich:

1. Rzeczywistość: wielokulturowość często objawia się w sytuacjach wyraźnie - choć nie wyłącznie - naznaczonych indywidualizmem, egocentryzmem, dezintegracją społeczną, podejrzliwością i strachem w odniesieniu do „drugiego człowieka” - obcokrajowca, często po-

2 Spośród licznych szkół, które są inspirowane „,pedagogią komunii”, wymienię następujące: Scuola Fantasy (Serbia), Zraka Sunca (Chorwacja), Biseri (Macedonia), Diamante e Santa Maria (Meksyk), Aurora e Santa Maria (Brazylia), Aurora de un mundo nuevo (Argentyna), Café con leche (Rep. Dominikana), Sol Naciente (Kolumbia).

3 Por. Mariola T. Kozubek, ,Dialog międzyreligijny w życiu i działalności Ruchu Focolari”, Paedagogia Christiana 1/27 (2011): 99-117. 
strzeganego jako wroga. Są to trendy kulturowe z pewnością obecne w naszym zachodnim świecie, jak wynika z licznych raportów badawczych, ale które teraz wydają się rozprzestrzeniać w większym stopniu, występują częściej i są zauważane na skutek gospodarczej globalizacji i jej kulturowych konsekwencji. Podobnie w ujęciu teoretycznym wielokulturowość-komunitaryzm podkreśla obronę różnorodności aż do negatywnych odczuć lub braku uzasadnienia dla „krzyżowania się ras kulturowych”, absolutyzując relatywizm kulturowy i - w ślad za tym - relatywizm etyczny (zaprzeczając tym samym możliwości wspólnego uznawania uniwersalnych wartości oraz powszechnych i uniwersalnych praw i obowiązków).

Lubich: nikt nie jest mi obcy, każda istota ludzka jest drugim bratem, który chce być kochanym, ponieważ jest podobny do mnie, co więcej, ponieważ widzę w nim Chrystusa. Konkretna miłość, która staje się dialogiem i twórczym związkiem, widzi w każdym brata. Ewangeliczne przykazanie „miłuj nieprzyjaciół” jest szczególnie aktualne w myśli Lubich, dotyczącej relacji osobowych oraz rzeczywistości duchowości wspólnotowej. Myśl ta jest zbudowana na pedagogii komunii, która zakłada bezinteresowność, dbałość o zaangażowanie społeczne, aktywne budowanie wspólnotowej tkanki społecznej, nowego miasta, a w konsekwencji nowej ludzkości, która potrafi pokonywać granice ze świadomością przynależności do świata i konieczności bycia „człowiekiem-światem”, „ludźmi planetarnymi"4.

2. Rzeczywistość: pojawiają się różne rodzaje reakcji na rzeczywistość wielokulturową, między innymi asymilacja, czyli postawa przystosowująca się do modelu dominującego, oraz kulturowy apartheid, który generuje podziały, getto, kulturowy sprzeciw. Tworzą się „odrębne społeczności”.

Lubich: każda osoba ludzka jest wyjątkowa, ma swoje własne powołanie w świecie, także każda kulturowa rzeczywistość jest unikalna, każdy człowiek jest wyjątkowy, nawet każdy kontynent ma

${ }^{4}$ Wystarczy wspomnieć kilka tekstów, jakkolwiek z okresu późniejszego niż profetyczne wykłady Lubich, lecz wskazujących na podobne cele pedagogiczne: Ernesto Balducci, L'uomo planetario (Milano: Camunia, 1985). Edgar Morin pisze, że jest konieczne „dążenie do hominizacji w humanizacji dzięki dostępowi do obywatelstwa ziemskiego w społeczności planetarnej" [Edgar Morin, I sette saperi necessari all'educazione del futuro (Milano: Raffaello Cortina, 2001), 122]. 
określoną i dominującą tożsamość oraz kulturowy koloryt, który należy szanować. W tej perspektywie propozycja Lubich jest niewątpliwie kontestująca w odniesieniu do konformizmu kulturowego, prowadzi do unikalnego stwierdzenia: wspólnota jest dynamiczną grą różnic, jest to wielość, która w świecie wartości znajduje jednak tajemnicę jedności, jest „wspólnotą wspólnot”s: żadna społeczność nie jest „odrębna”, każda tożsamość kulturowa otwiera swoje granice i jest częścią szerszej społeczności inkluzywnej.

3. Rzeczywistość: obcokrajowcy są często postrzegani przez soczewki uniwersalizujące, jako np. istoty powierzchowne; pomiędzy różnymi jednostkami kulturowymi łatwo powstają asymetryczne relacje podporządkowania (,kultura hegemoniczna” - „kultura podporządkowana"), up-down - relacje zależności, których powstanie ułatwiają „mity o własnej doskonałości/wyższości i niedoskonałości/niższości drugiego" lub - przeciwnie - „o własnej niższości i wyższości innych".

Lubich: wzajemność, oparta na miłości konkretnej, implikująca szacunek wobec drugiego, przezwyciężanie pokusy wyższości, pokorna gościnność, co naturalnie sprzeciwia się wszelkiemu zarozumialstwu, aby budować na wszystkich poziomach relacje zdolne do ,jednoczenia się", empatii, widzenia odniesień między kulturami nie w sensie kolonizacji, jak to się często zdarza, ale w perspektywie wzajemnej inkulturacji, która ubogaca tożsamość zamiast ją zubażać lub niszczyć; właśnie w symetrii możliwości znajduje podstawę do budowy wspólnego świata.

4. Rzeczywistość: doświadczenie migracji jest często wynikiem planowania, decydowania, które aktywnie ukierunkowuje tworzenie się przyszłości; jednak należy stwierdzić, że powszechne nadużywanie opieki społecznej (zwłaszcza ze strony instytucji krajów przyjmujących) często przeciwstawia się tym planom, hamując wyzwanie podjęte przez osoby podróżujące, emigrujące, zamieszkujące; opieka społeczna (której nie towarzyszy inteligentne wychowanie) czę-

5 Sformułowanie ,wspólnota wspólnot” zostało zaproponowane (w nawiązaniu do łacińskiego terminu communitas communitatum) przez Martina Bubera już w 1950 r. w jego Sentieri in Utopia (Milano: Ed. Di Comunità, 1967) [Por. Giuseppe Milan, Educare all'incontro. La Pedagogia di Martin Buber (Roma: Città Nuova Editrice, 1994), 134-138]. Ta sama koncepcja w raporcie nt. aktualnej sytuacji geopolitycznej [Pasquale Ferrara, La politica inframondiale (Roma: Città Nuova Editrice, 2014)]. 
sto sprowadza się do biernego przystosowywania się do zajętych pozycji, całkowicie pozbawiając inicjatywy, uniemożliwiając bycie/ stawanie się uczestnikami procesów społeczno-kulturalno-politycznych; przystosowywanie się - począwszy od ogólnej, uniwersalnej koncepcji - absolutyzuje natomiast podobieństwa i tym samym konformizm, kulturowy uniformizm, ryzykując doprowadzenie do ,jednolitego myślenia" w kulturalnej monotonii z jakimś mało prawdopodobnym powrotem do ,monokultury”.

Lubich: każda osoba ludzka jest powołana do bycia podmiotem, dlatego należy promować odpowiedzialność osobistą i wspólnotową. Tak zwane relacje wspomagające nie powinny hamować odgrywania głównych ról przez innych, przeciwnie - ich zadaniem jest wzmocnić pojedyncze projekty zarówno jednostkowe, jak i grupowe. Doświadczeniem wielu członków Ruchu Focolari jest „doświadczenie podróży", przeniesienia się w środowiska kulturowe różne od własnych, w których nie są „biernymi obcokrajowcami”, ale „obcokrajowcami aktywnymi”, zaangażowanymi w udoskonalanie środowiska i tym samym w kreatywne integrowanie się w nowym otoczeniu.

5. Rzeczywistość: wielokulturowość wiąże ze sobą tradycje, obyczaje, przyzwyczajenia, przynależności religijne, wizje świata, które zmuszone do zbliżenia i konfrontacji - mogą powodować trudności, a w niektórych przypadkach wrogość i nietolerancję ${ }^{6}$.

Lubich: sztuka dialogu oparta na miłości przynosi skuteczną otwartość na wymiar „pomiędzy”, czyli na możliwości międzykulturowego i międzyreligijnego dialogu: inne tradycje, różne zwyczaje, różne wyznania religijne nie są postrzegane jako przeszkody, problemy lub wrogie elementy, które powodują powstawanie murów. Wychowanie międzykulturowe jako doświadczenie autentycznej wzajemności działa również jako perspektywa „kontrastująca”: lepiej rozumiem siebie, moją tożsamość, moją kulturę, jeżeli mam

${ }^{6}$ Może być interesujące pogłębienie koncepcji autochtonizmu [por. Mircea Eliade, Miti sogni e misteri (Milano: Rusconi, 1976); Giuseppe Milan, „Dal «metodo per le vie brevi» al dialogo in profondità e in altezza. Creatività per l'intercultura", Studium Educationis 2 (2015): 115-126; Giuseppe Milan, Margherita Cestaro, We Can Change. Seconde generazioni. Mediazione interculturale, città (Lecce: Pensa MultiMedia, 2016), 18-28]. 
możliwość skonfrontowania się z inną tożsamością i inną kulturą (rozwijam siebie poprzez innych) ${ }^{7}$.

\section{Strategie wychowania międzykulturowego}

Świadomie realizowana międzykulturowość jest przedsięwzięciem trudnym, wymaga bowiem uznania ,jedności w różnorodności” za możliwą, a nawet pożądaną w naszych relacjach, od mikrokosmosu naszych bliskich związków, naszych codziennych „małych światów”, aż do wymiaru planetarnego.

Propozycja Chiary Lubich widzi międzykulturowość jako projekt, zaangażowanie, zadanie, które ewidentnie dotyczy wielu dziedzin ludzkiej aktywności, które staje się głęboko odnowione, tak że sama Lubich, w perspektywie „Nowej ludzkości”, przekazuje pewne sugestie dotyczące prac badawczych nad rozwojem „nowej polityki”, „nowego prawa”, „nowej sztuki”, „nowej ekonomii”, „nowej medycyny” itd. Możemy rozumieć atrybut „nowy/nowa” także jako odnoszący się do „komunii” (np. „Ekonomia komunii”), która dla Lubich oznacza także „międzykulturowość”: „polityka międzykulturowa”, „sztuka międzykulturowa”, „medycyna międzykulturowa” itp.

I jest oczywiste, że przypisuje ona zasadniczą, pierwszorzędną rolę wychowaniu: jest nie do pomyślenia, aby zbudować międzykulturowe polis inaczej niż poprzez znaczący wkład w ,nowe wychowanie”, a więc „pedagogię komunii” czy ,pedagogię międzykulturową".

Możemy zatem zadać sobie pytanie: jakie szczególne aspekty myśli i działań Lubich wiążą się z zaangażowaniem pedagogicznym w perspektywie międzykulturowości? Oto niektóre cechy wychowania międzykulturowego w ujęciu syntetycznym:

1. Dla Lubich międzykulturowość jest wymiarem typowym dla bytu ludzkiego postrzeganego jako dialogiczny. Dlatego wychowanie międzykulturowe jest nie tyle jednym z wielu przedmiotów wychowania, jakimś działem: międzykulturowość winna być postrzegana jako wymiar przekrojowy, który dotyczy całej pracy wychowawczej. Nie można myśleć o wychowaniu, które nie jest międzykulturowe (powszechność międzykulturowa w wychowaniu).

\footnotetext{
7 Odnośnie do tego zagadnienia zob. Milan, Educare (część pierwsza).

${ }^{8}$ Por. Tommaso Sorgi, Costruire il sociale. La persona e i suoi «Piccoli mondi» (Roma: Città Nuova Editrice, 1998).
} 
2. Nie jest to działalność wychowawcza zarezerwowana dla wydzielonej kategorii, np. dla „uczniów obcokrajowców w szkole”, dla rodzin obcego pochodzenia przebywających na danym terytorium. Odnosi się ona do sposobu życia (modus vivendi), który wpływa na każdego człowieka, dlatego też dotyczy każdego z osobna i wszystkich razem: każda istota ludzka ma potrzebę otwierania się na inność, na przyjęcie drugiego, wzajemność, solidarność, braterstwo (są to „kluczowe hasła” międzykulturowości).

3. Przed podjęciem tematu międzykulturowości jako pewnej konstrukcji społeczno-kulturowo-polityczno-organizacyjnej perspektywa wychowawcza Lubich ukierunkowana jest na „człowieka-dialog” (z perspektywy teologicznej możemy mówić o osobie żyjącej w wymiarze trynitarnym, na wzór Chrystusa, będąc obrazem Boga): podstawą, główną zasadą wychowawczą jest zatem ,podmiot międzykulturowy”, osoba zdolna być w wymiarze „inter-”, postępować w duchu dialogu pojedynczo i zbiorowo, być „gościem” w dynamice wzajemności ${ }^{9}$. Na podstawie tej „konstytutywnej relacyjności” buduje się międzykulturowość, także na poziomie makro, począwszy od poziomu mikro, od każdego, od przedmiotu (jest to szczególny wkład w proces wychowawczy); można powiedzieć, że antropologiczno-etyczno-pedagogiczny wymiar międzykulturowości poprzedza wymiar kulturowo-społeczno-polityczny. Bardzo ważna w myśli Lubich jest taka determinacja „wychowawcza”, która natychmiastowo i w nieunikniony sposób odnosi się do wyjątkowości człowieka, do odpowiedzialności każdego jako do elementu nośnego wspólnotowej i międzykulturowej konstrukcji.

4. Międzykulturowy projekt wychowawczy powinien być „systemowy" i przewidywać dzielenie/współpracę/współdziałanie/sieć pomiędzy podstawowymi środowiskami wychowawczymi: rodziną, szkołą, stowarzyszeniami, instytucjami, mass mediami (systemowość wychowania międzykulturowego) ${ }^{10}$. W tym względzie doświadczenie Ruchu Focolari jest naprawdę istotne i wzorcowe, ponieważ żadna instytucja, żadna kategoria nie jest wykluczona ze wspólnego zadania: wszyscy są „członkami systemu”, głównymi

${ }^{9}$ Por. Giuseppe Milan, „Ospitarsi”, w: Intercultura, red. Anna Granata (Roma: Città Nuova Editrice, 2012).

${ }^{10}$ Una città ben fatta. Il gioco creativo delle differenze, red. Giuseppe Milan, Emma Gasperi (Lecce: Pensa MultiMedia, 2012). 
podmiotami przenikającego się projektu systemowego, który jednocześnie promuje i dowartościowuje indywidualny wkład każdej osoby.

5. Kultury nie są postrzegane jako skonkretyzowane, monolityczne, hermetyczne, nieprzepuszczalne: podobnie jak ludzie, są przedmiotem takich procesów zmian, które są powodowane zwłaszcza przez relacje, przez konstruktywne kontaminacje w twórczym spotkaniu interpersonalnym, społecznym, międzykulturowym; kultury są zatem niespoiste, zawsze zmienne, dynamiczne, z granicami umożliwiającymi przenikanie.

6. W takiej perspektywie pedagogicznej, obecnej we wszystkich dziełach Chiary Lubich, osoba ludzka jest postrzegana jako uczestnik - w całym tego słowa znaczeniu - międzykulturowości: jest to kultura, ale nie sprowadza się w sposób zdeterminowany do jakiejś jednej kultury, dzięki wolności, jaka ją cechuje, jest w stanie uwolnić się ze swojej kultury, wyodrębnić ją i kreatywnie wyjść poza swoją przynależność do niej, czyniąc ją tym samym „porowatą”. Człowiek otrzymuje wiele poprzez kulturę, jest przez nią uwarunkowywany, ale nie zdeterminowany. Osoby ludzkie są więc pierwszymi katalizatorami międzykulturowości: to nie tyle kultury się spotykają, ile osoby różnych kultur utrzymują pomiędzy sobą żywą komunikację: to, co się liczy, to relacja z drugą osobą, a nie stosunek do swojej kultury w sensie abstrakcyjnym. Jest to doświadczenie, jakie przeżywali członkowie Ruchu od samego jego początku, czerpiąc właśnie z tej ,plastyczności kulturowej” poprzez przebywanie w środowiskach różnych kultur i ubogacając się życiowo tym międzykulturowym elementem.

7. Wychowanie międzykulturowe podkreśla znaczenie bazy transkulturowej: istnieje pewien rdzeń wspólnych, współdzielonych wartości, które Lubich definiuje jako „Ziarna Słowa” i które reprezentują wspólną dla różnych ,światów" podstawę etyczną. Praca wychowawcza kładzie nacisk na znaczenie i promocję tych wartości, które wraz z ludźmi działają jako czynniki łączące (czynniki przeplatające się międzykulturowo). Na tym wspólnym logosie, często ukrytym, ale o niezwykłym znaczeniu, można naprawdę budować „Nową Ludzkość”, która także dzięki przynależności do wartości uniwersalnych - postrzeganych nie dogmatycznie, ale jako elementy siły napędowej nieustannego doskonalenia się - może i powinna znaleźć ,jedność w wielości”. 
8. Wychowanie międzykulturowe promuje stopniowe pokonywanie odległości międzyludzkich i kulturowych w przechodzeniu od bazowego poziomu tolerancji (co implikuje gotowość do uznania różnorodności drugiej osoby, często postrzeganej jako nastawienie pozytywne, ale również jako wada) do poziomu akceptacji - szacunku dla różnorodności drugiego, do wzajemnego wspierania się (każdy wyraża szacunek dla drugiego), do braterskiej solidarności (która pobudza do działania razem w celu rozwiązania wspólnych problemów), aby dojść do tego wzajemnego zaufania, jakie umie także wskazać na niedoskonałości i zaakceptować wzajemną krytykę przy realizacji wspólnego projektu.

9. Te wskazania odnośnie do wyznaczonej drogi, metodologicznie niezbędne w przechodzeniu od rzeczywistości-wyzwania do celów wskazanych przez międzykulturowość, są efektywnie przekazywane przez Lubich w jej fundamentalnym dziele Sztuka miłowania ${ }^{11}$, w której przedstawia sekret relacji międzyosobowej, społecznej, międzykulturowej, postawy nie do pominięcia, która realizuje się poprzez „konkretną miłość”.

10. W środowisku szkolno-dydaktycznym perspektywa międzykulturowości powinna uwzględniać interdyscyplinarność (żadna dyscyplina nie jest wykluczana) i wymaga dojrzałej formacji pedagogicznej wychowawców na wszystkich poziomach.

Przedstawione w sposób syntetyczny w tym artykule kluczowe idee są obecne i szeroko uzasadniane w wielu pismach Chiary Lubich; wnoszą one znaczący wkład w problematykę międzykulturowości, a w dialogu z innymi myślicielami wykazują istotną zgodność. Tytułem przykładu chciałbym tu wymienić trzy bardzo znaczące fragmenty, które różnią się pomiędzy sobą czasem publikacji o ponad 20 lat, a które opiszę w porządku chronologicznym; przedstawiają one główne zasady reprezentujące to podejście kulturowo-pedagogiczne:

- z przemówienia Dla czlowieka-świata ${ }^{12}$, prawdziwie proroczego, wygłoszonego w 1972 r., kiedy wyzwanie międzykulturowe nie było jeszcze tak intensywne i natarczywe jak to odczuwamy dzisiaj:

${ }^{11}$ Chiara Lubich, L'arte di amare (Roma: Città Nuova Editrice, 2005).

${ }_{12}$ Chiara Lubich, Colloqui con i gen, 1970-1974 (Roma: Città Nuova Editrice, 1999), $73-82$. 
W epoce bomby atomowej, w czasach, gdy została rozerwana jedność, którą uważano za niepodzielną, jedność atomu, Niebo dało nam odkryć boską bombę atomową, to jest potężną broń miłości, która zamiast niszczyć, równać z ziemią ludzkość, wynosi ją w najwyższym stopniu, przyznając jej najwyższą godność, dając poczucie, że nie jesteśmy jakimś zlepkiem różnych narodów, które często się kłócą i grożą sobie jak niegrzeczni i groźni chłopcy, ale że stanowimy jeden lud, lud Boży. Broń ta przynosi jedność na ziemię [...]. Chciałabym powiedzieć raczej o nowej sytuacji, w jakiej się znaleźliśmy po już nieodwracalnym spotkaniu narodów i cywilizacji całego świata. Spotkanie to stało się możliwe i zostało przyspieszone przez prawdziwą eksplozję środków masowego przekazu i ogromny rozwój technologii.

To spotkanie z pewnością przyniosło wiele dobrego, ponieważ umożliwiło krążenie wiadomości, wiedzy, faktów, zdarzeń, tradycji, mentalności, czyniąc wszystko dostępne, pobudzając każdego człowieka do wyjścia poza własny naród i kulturę, w których żył do tej pory. [...] Ale jest też druga strona medalu. Nie zawsze współczesny człowiek jest przygotowany na to spotkanie [...]. Dopiero teraz zaczynamy zbliżać się do tych ludzi z pełnią szacunku, z pokorą człowieka, który wie, że musi stale się uczyć, i dlatego zauważamy, że istnieje zupełnie nowy sposób widzenia tych samych rzeczy, bardzo różniący się od naszego, nas, ludzi Zachodu, ale też z tego powodu nie mniej słuszny lub mniej ważny [...]. Różne koncepcje, tradycje, mentalności w szybkiej konfrontacji z innymi sposobami myślenia, innymi tradycjami nie są w stanie się oprzeć. Wtedy pojawia się poczucie bolesnej niepewności, cierpienia, które mniej lub bardziej odczuwa cała ludzkość, a na pewno odczuje, gdy różne miejsca na ziemi zostaną poruszone i zderzą się z innymi ludami, nigdy wcześniej niepoznanymi.

A dlaczego tak jest? Właśnie dlatego, że struktura mentalna ludzi Zacho$\mathrm{du}$, ich sposób myślenia, jest czasami ściśle połączony z wartościami absolutnymi, które zawiera ta struktura - jak kielich zawierający wyborne wino - gdy kielich się rozbije, straci się także wino; uważa się, że gdy upada struktura mentalna, to upadają także wielkie wartości ludzkie, takie jak etyka, moralność, estetyka, piękno, metafizyka, wolność, sprawiedliwość [...]. Czy istnieje odpowiedź [...], jakiś niezawodny środek, na który można liczyć, aby wraz z innymi tworzyć świat, który nadejdzie?

Czy istnieje taki człowiek-świat, który czuje, który czuł w sobie to straszne tsunami, grożące, że nie ocaleje nic z tego, co do tej pory uważano za nietykalne? Człowiek, który sądząc, że sama prawda absolutna opuściła go, rzucając go w otchłań najcięższego zamieszania - potrafił przezwyciężyć tę próbę, płacąc w ten sposób za narodziny nowego świata, który odnalazł w sobie i zrodził dla innych? 
Tak, istnieje.

Ale od razu zdajemy sobie sprawę, że ten człowiek nie mógł być tylko zwykłym człowiekiem, ale jakimś wyjątkowym Człowiekiem. Jest nim Jezus opuszczony. [...] Musicie poznać Go jak najgłębiej, żyć Nim [...], aby zapoczątkować ten niezbędny i decydujący przełom, przed którym stoi ludzkość!

Od was zależy, czy przyjmiecie do serca Jezusa opuszczonego jako najcenniejszą perłę, jaką można wam przekazać, dla waszej duszy, dla narodów, które tutaj reprezentujecie, ale przede wszystkim dla tego nowego świata, który musi zobaczyć wszystkich ludzi zjednoczonymi. Dla tego nowego świata, który przyjmie nie wiele podzielonych ludów, ale jedyny lud Boży ${ }^{13}$.

- z przemówienia, które Chiara Lubich wygłosiła w Paryżu 17 grudnia 1996 r. z okazji przyznania jej nagrody UNESCO za Wychowanie do Pokoju:

Ta duchowość wspólnotowa niekoniecznie jest związana z jakimś Kościołem: jest uniwersalna, więc mogą nią żyć wszyscy. Dzięki niej bowiem otwarte zostały owocne dialogi ze wszystkimi ludźmi, z chrześcijanami wielu Kościołów, $\mathrm{z}$ wyznawcami różnych religii i z osobami różnych kultur, którzy odnajdują w niej wartości, w które wierzą. I wspólnie dążymy do tej pełni prawdy, której wszyscy pragniemy. Dzięki tej duchowości dzisiaj ludzie niemal wszystkich narodów świata stopniowo, lecz zdecydowanie próbują stawać się wszędzie tam, gdzie żyją, zalążkami nowego ludu, świata bardziej zjednoczonego, świata pokoju, świata bardziej solidarnego zwłaszcza z najmniejszymi, z najuboższymi ${ }^{14}$.

- $\quad$ z wykładu (lectio magistralis), który Chiara Lubich wygłosiła w Waszyngtonie 10 listopada 2000 r. (po otrzymaniu doktoratu honoris causa $\mathrm{w}$ zakresie pedagogiki):

Nasze doświadczenie życia wspólnotowego ma swoje źródło w zachęcie Jezusa: „Miłujcie się wzajemnie, jak Ja was umiłowałem [...] Bądźcie jedno” (por. J 15,$12 ; 17,21$ ). Jest to motywacja natury religijnej, ale jej skutki na polu wychowania są niezwykłe. Cel, jaki zawsze stawiano wychowaniu (kształto-

${ }^{13}$ Chiara Lubich, Jezus Opuszczony (Warszawa-Rzeszów: Fundacja Mariapoli, Indygo, 2015), 97-99.

${ }^{14}$ Chiara Lubich, Charyzmat jedności (Kraków: Fundacja Mariapoli, Wydawnictwo M, 2007), 48. 
waniu człowieka, jego autonomii), osiągalny jest prawie paradoksalnie poprzez kształtowanie człowieka-relacji, który dla nas oznacza człowieka-ikonę Trójcy Świętej, zdolnego do nieustannego wychodzenia poza siebie w rzeczywistości Jezusa obecnego pośród nas. Dzięki tej duchowej i wychowawczej praktyce miłości wzajemnej, stapiania się w jedno (rzeczywistości praktykowanej przez wszystkich członków Ruchu powołanych do życia duchowością wspólnotową w małych grupach), dajemy swój wkład dla owego najwyższego celu, wyrażonego w modlitwie-testamencie Jezusa: Aby wszyscy stanowili jedno; dla tej Utopii-Rzeczywistości, której pragniemy poświęcić nasze życie jako Jego narzędzia [...]. Oczywiście Jezus, który przeszedł przez cały proces wychowania to przechodzenie między opuszczeniem a Trójcą Świętą; On, który w swym ziemskim życiu przeżywał do głębi relację z innymi przez empatię, akceptację, nadzieję, zmagania wychowawcze, życie jednością z Ojcem i ze swymi uczniami - jest najbardziej autentycznym i wymagającym świadkiem prawdziwego wychowawcy ${ }^{15}$.

\section{Podsumowanie}

Zaprezentowana w niniejszym artykule perspektywa teoretyczno-praktyczna potrzebuje niewątpliwie sporego zaangażowania przekrojowego, które skierowane jest do każdego z nas - dążących do przemiany świata - a także do wspólnot, grup, różnych tożsamości kulturowych, narodów, do wszystkich podmiotów działających na polu szeroko rozumianych relacji międzyludzkich w perspektywie postrzegania całej ludzkości jako „wspólnoty wspólnot” (communitas communitatum). Jest oczywiste, że wszyscy jesteśmy zaangażowani w powołaniu, które pochodzi „Z wysoka” $\mathrm{i}$ które jest odpowiedzią na wezwanie, włączające istotę ludzką w niewysłowiony wymiar „relacji trynitarnej”, i które jednocześnie pochodzi „z dołu” jako aktywna reakcja na pragnienie ludzkości, by była postrzegana jako ,jedność w wielości”, jako „radość wspólnego życia pomimo różnic”, a zatem jako międzykulturowość.

Jest to wyzwanie, które współcześnie określa się jako pilne, a nawet jako wywrotowe, ponieważ od korzeni burzy utrwaloną antropologię indywidualistyczną i egocentryczną, proponując antropologiczny paradygmat tożsamości dialogiczno-trynitarno-międzykulturowy, który jawi się jako prawdziwie innowacyjny, a zatem szczególnie trudny do zrozumienia, przyjęcia i życia zgodnie z nim.

15 Lubich, „Charyzmat”, 319-320. 
Myślę, że właśnie wychowanie może spełniać dzisiaj „funkcję przebudzającą": spowodować podjęcie działań w wymiarze ogólnoświatowym, co prawda wielce ryzykownych, znieczulających nasze energie duchowe, somnambulizm egzystencjalny, kulturowy i polityczny, i - w tym wyalienowanym kontekście - doprowadzić do „przebudzenia” ludzkości, w każdym i między wszystkimi.

W tak ukierunkowanym zaangażowaniu wychowawczo-kulturalno-politycznym istnieje ogromna potrzeba wiarygodnych i rzetelnych świadków, którzy słowem i czynem, myślą i działaniem będą w stanie otworzyć nowe drogi i - że tak powiem - działać jako przewodnicy w złożonych i trudnych przedsięwzięciach. Chiara Lubich doświadczyła tego i czyni to nadal poprzez ogromne świadectwo zawarte w jej myśli i życiu, które nam pozostawiła. Międzykulturowość z pewnością jest pewnym projektem niedokończonym, który prowokuje i zachęca nas do nieustannego posuwania się naprzód $\mathrm{w}$ tej perspektywie, nawet wbrew przeciwnościom, które często blokują nam drogę. Mamy jednak wiele zasobów otrzymanych z wysoka, które pomagają nam być także jako osoby międzykulturowe poszukiwaczami nieskończoności.

Ttumaczenie: Stanistaw Grochmal

\section{Bibliografia}

Balducci, Ernesto. L'uomo planetario. Milano: Camunia, 1985.

Buber, Martin. Sentieri in Utopia. Milano: Edizione di Comunità, 1967.

Eliade, Mircea. Miti sogni e misteri. Milano: Rusconi, 1976.

Ferrara, Pasquale. La politica inframondiale. Roma: Città Nuova, 2014.

Kozubek, Mariola. „Dialog międzyreligijny w życiu i działalności Ruchu Focolari”. Paedagogia Christiana 1/27 (2011): 99-117.

Lubich, Chiara. „Charyzmat jedności i pedagogika”. W: Chiara Lubich. Charyzmat jedności, red. Michel Vandeleene, 313-320. Kraków: Fundacja Mariapoli, Wydawnictwo M, 2007.

Lubich, Chiara. Colloqui con i gen, 1970-1974. Roma: Citta Nuova, 1999.

Lubich, Chiara. Jezus Opuszczony. Warszawa-Rzeszów: Fundacja Mariapoli, Indygo, 2015.

Lubich, Chiara. L'arte di amare. Roma: Città Nuova, 2005.

Milan, Giuseppe, Margherita Cestaro. We Can Change. Seconde generazioni. Mediazione interculturale, città. Lecce Pensa: MultiMedia, 2016. 
Milan, Giuseppe. "Dal «metodo per le vie brevi» al dialogo in profondità e in altezza. Creatività per l'intercultura". Studium Educationis 2 (2015): 115-126.

Milan, Giuseppe. "Ospitarsi”. In: Intercultura, ed. Anna Granata, 137-150. Roma: Città Nuova, 2012.

Milan, Giuseppe. Educare all'incontro. La Pedagogia di Martin Buber. Roma: Città Nuova, 1994.

Morin, Edgar. I sette saperi necessari all'educazione del futuro. Milano: Raffaello Cortina, 2001.

Sorgi, Tommaso. Costruire il sociale. La persona e i suoi «Piccoli mondi». Roma: Città Nuova, 1998.

Una città ben fatta. Il gioco creativo delle differenze, red. Giuseppe Milan, Emma Gasperi. Lecce: Pensa MultiMedia, 2012. 